\title{
Traceability of raw materials processes in the steel industry
}

\section{Trazabilidad de procesos de materias primas en la industria acerera}

\author{
SILVA-AVILA, Alicia Elena†*, CASTORENA-PEÑA, Jesús Abraham, DOMINGUEZ-LUGO, Alma \\ Jovita and RODRÍGUEZ-MONTELONGO, Diana Laura
}

Universidad Autónoma de Coahuila. Barranquilla S/N, colonia Guadalupe C. P. 25750Monclova, Coah

ID $1^{\text {st }}$ Author: Alicia Elena, Silva-Avila / ORC ID: 0000-0001-7093-9898, CVU CONACYT ID: 260461

ID $1^{\text {st }}$ Coauthor: Jesús Abraham, Castorena-Peña / ORC ID: 0000-0002-8833-1159, CVU CONACYT ID: 411532

ID $2^{\text {nd }}$ Coauthor: Alma Jovita, Dominguez-Lugo / ORC ID: 0000-0003-4988-4911, CVU CONACYT ID: 260410

ID $3^{\text {rd }}$ Coauthor: Diana Laura, Rodríguez-Montelongo / ORC ID: 0000-0003-4535-3363

DOI: 10.35429/JBDS.2019.16.5.1.5

Received September 03, 2019; Accepted November 30, 2019

\begin{abstract}
Companies today experience extreme competition, mainly due to the growing pressures of technology changes and global challenges. These "emerging" pressures result in globalization of manufacturing, characterized by faster material transfers, complex payment systems and compression of product life cycles, which drives the need for superior integration of technologies with the needs of customers increasingly sophisticated. Because of this technological change, the processes that were done manually in a company are no longer very helpful, due to the constant errors that occur in their time of execution and response. Given the previous context, the objective was to develop a system based on SCRUM software development methodologies (name that comes from a certain play that takes place during a rugby match), using C \# 2017 software and Microsoft SQL Server 2012; In this way, the contribution that will be made will be to allow the area of raw materials and central laboratory within a steel company, to track the processes, thereby speeding up the release of materials.
\end{abstract}

Traceability, SCRUM methodology, Software, Raw materials

\begin{abstract}
Resumen
Las empresas hoy en día experimentan una competencia extrema, principalmente debido a las crecientes presiones de los cambios de la tecnología y desafíos globales. Estas presiones "emergentes" resultan en la globalización de fabricación, caracterizada por transferencias de materiales más rápidas, sistemas de pago complejos y compresión de los ciclos de vida de los productos, lo que impulsa la necesidad de una integración superior de tecnologías con las necesidades de los clientes cada vez más sofisticadas. A causa de este cambio tecnológico los procesos que se hacían manualmente en una empresa ya no son de mucha ayuda, debido a los constantes errores que se producen en su tiempo tardado de ejecución y respuesta. Dado el contexto anterior, el objetivo fue, desarrollar un sistema basado en las metodologías de desarrollo de software SCRUM (nombre que proviene de cierta jugada que tiene lugar durante un partido de rugby), usando el software de C\# 2017 y Microsoft SQL Server 2012; de esta manera la contribución que se aportará será el permitir a el área de materias primas y laboratorio central dentro de una empresa acerera, tener rastreo de los procesos agilizando con esto la liberación de materiales.
\end{abstract}

Trazabilidad, Metodología SCRUM, Software, Materias primas

Citation: SILVA-AVILA, Alicia Elena, CASTORENA-PEÑA, Jesús Abraham, DOMINGUEZ-LUGO, Alma Jovita and RODRÍGUEZ-MONTELONGO, Diana Laura. Traceability of raw materials processes in the steel industry. Journal of Business Development Strategies. 2019, 5-16: 1-5

\footnotetext{
$\uparrow$ Researcher contributing first author
} 


\section{Introduction}

Computer software remains the most important technology on the world stage. It is also a magnificent example of the law of unexpected consequences. 50 years ago, nobody could have predicted that software would become an indispensable technology for business, science and engineering, nor that it would allow the creation of new technologies (for example, genetic engineering and nanotechnology), the expansion of existing technologies (telecommunications) and the radical change of old technologies (the printing industry).

Nor that software would be the force that would drive the personal computer revolution, that packaged software products would be bought in supermarkets, that software would gradually evolve from a product to a service when software companies "on demand" provided functionality just in time through a web browser (Acosta \& Navarrete, 2013), that a software company would be larger and would have more influence than almost all companies of the industrial era, that a vast network called the internet would be operated with software and everything would evolve and change, from library research and buying consumer products.

In the last half century, the role of computer software has undergone a significant change. The remarkable improvements in hardware performance, the profound changes in computer architectures, the large increase in memory and storage capacity, and a wide variety of exotic input and output options have led to the existence of more computer-based systems. sophisticated and complex. When a system is successful, sophistication and complexity produce dazzling results, but they also pose huge problems for those who must build complex systems (Hernández, 2003).

\section{Problem}

In a company, which is mainly engaged in steel production, there are two areas that are related to each other, which are central laboratory and raw materials. The raw materials area is responsible for collecting samples of all material that will be used within the processes for the generation of steel.
A record of the acquired samples must be kept, as well as the name of the material, date on which it was sampled, name of the supplier, the frequency on which it will be sampled until it is used up, the name of the worker who collected the sample, as well as the tests to be performed on the sample acquired. The tests are divided into granulometric, wet, density and chemical analysis tests. The first three are carried out within the area of raw materials while those of chemical analysis are performed in the central laboratory.

The central laboratory cannot perform any tests until the results obtained by raw materials are obtained, this causes the laboratory to be late for not obtaining the results in a timely manner, once all the tests have been completed, a document with all the results must be returned to raw materials so that this can release the material and thus continue the production process.

A record of the values obtained sent by the supplier is also kept in order to compare the results obtained from the tests performed by the laboratory staff to see if there are alterations in the results or if everything is in order and the material can be used in the processes.

Therefore, the proposed system will track the areas of raw materials and central laboratory, speeding up and ensuring precision in the processes and generating quality in their materials.

\section{Methodologies}

The Scrum principles are congruent with the agile manifesto and are used to guide development activities within an analysis process that incorporates the following structural activities: requirements, analysis, design, evolution and delivery (Sutherland, Viktorov, Blount \& Puntikov, 2007).

Within each structural activity, work tasks occur with a process pattern (which is studied in the following paragraph) called sprint. The work done within a sprint (the number of these required by each structural activity will vary depending on the complexity and size of the product) is adapted to the problem in question and is defined - and often modified - in real time by the Scrum team. 
The general flow of the Scrum process is illustrated in Figure 1. Scrum emphasizes the use of a set of software process patterns that have proven effective for projects with tight deadlines, changing requirements and critical businesses. Each of these process patterns defines a group of development actions (Mariño \& Alfonzo, 2014):

Delay: Priority list of the requirements or characteristics of the project that give the customer a business value. It is possible to add other aspects to the delay at any time (this is the way in which changes are made). The project manager evaluates the delay and updates priorities as required..

Sprints: It consists of work units that are needed to reach a defined requirement in the delay that must be adjusted in a predefined time box (30 days are common). No changes are introduced during the sprint (for example, aspects of delayed work). Thus, the sprint allows team members to work in a short-term but stable environment..

Scrum meetings: These are brief meetings (15 minutes, usually) that the Scrum team holds daily. There are three key questions that all team members are asked to answer:

- What have you done since the last team meeting?

- What obstacles are you encountering?

- What do you plan to do while the next team meeting arrives?

A team leader, called Scrum teacher, directs the board and evaluates each person's responses. The Scrum board helps the team discover potential problems as soon as possible. Likewise, these daily meetings lead to the "socialization of knowledge", which promotes a team structure with its own organization (Pressman, 2010).

Preliminary Demonstrations: deliver the software increment to the client so that the functionality that has been implemented can be demonstrated to the client and he can evaluate it. It is important to note that the preliminary demonstrations do not contain all the planned functionality, but that these will be delivered within the established time frame (Lozano, 2000), figure 1.

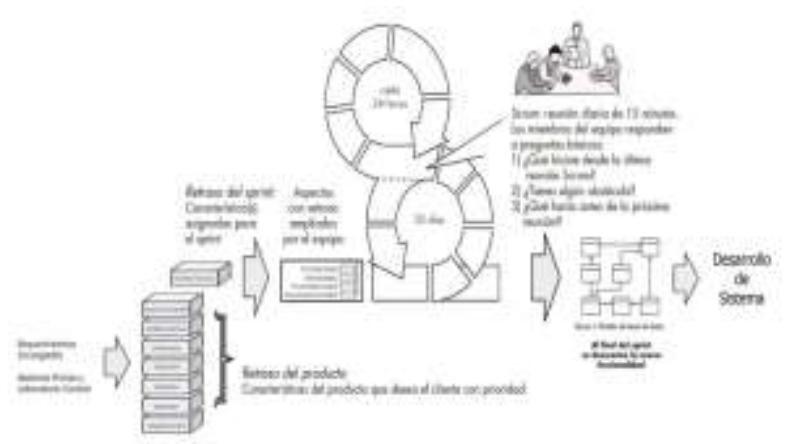

Figure 1 System development using SCRUM methodology

The database management system to build the data model was Microsoft SQL Server, which is a system for database management based on the relational model, whose main function is to store and query data requested by other applications, regardless of whether they are on the same computer, if they are connected in the local network or if they are connected through the internet (Garrido, 2014).

\section{Methodologies}

With the process followed in the Scrum methodology (figure 1) the design of the database (figure 2) was obtained, which was used to develop the proposed system (figures $3,4)$ corresponding to the specific needs of the users of the Raw materials department and central laboratory. SQL Server 2012 was used for the relational database and was programmed in C \# 2017.

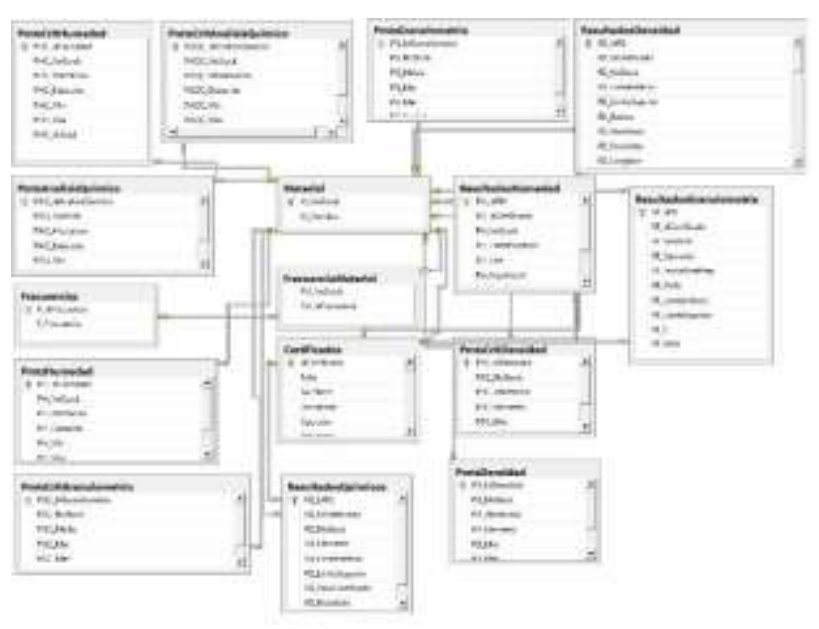

Figure 2 Relational database design

Next, in figure 3 , all the materials are shown, as well as their identification numbers that are registered within the company for daily use. 


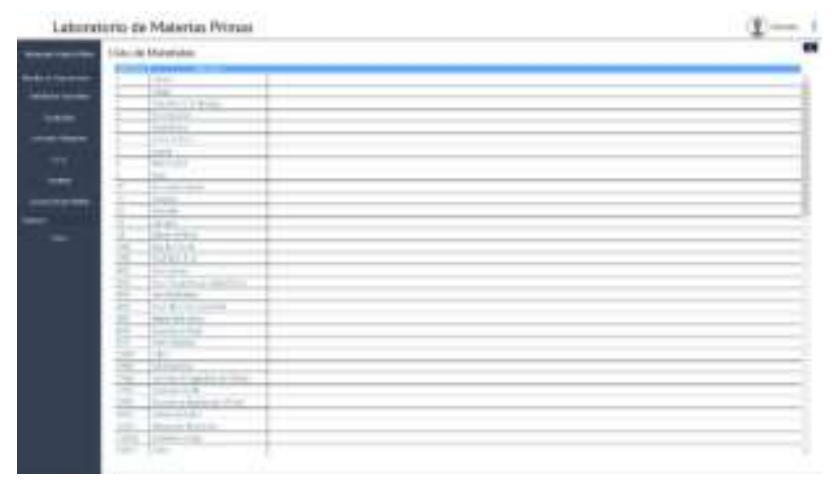

Figure 3 Receipt of Raw Materials

In figure 4, all the applications that are registered under the selected material are shown. Together with the date it was registered, as well as the quantity of material, the order number, the supplier to which it belongs and the reference number.

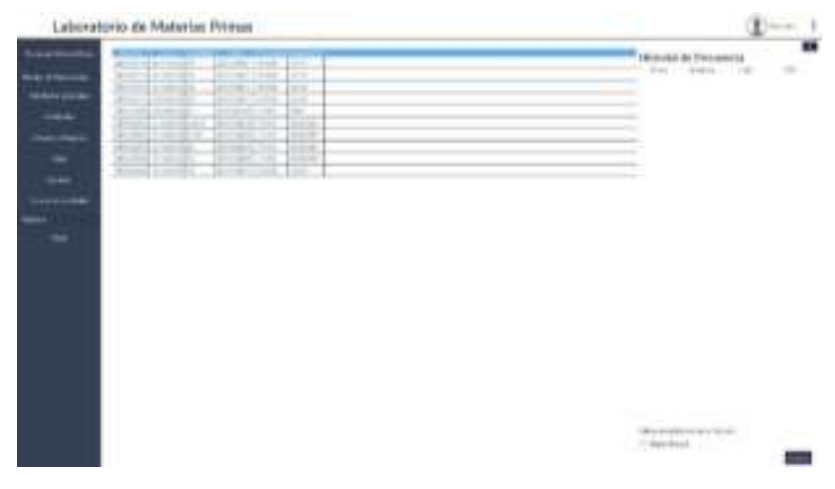

Figure 4 Receipt of Raw Materials

In figure 5, the material corresponding to the request that is chosen by the user appears in the previous screen (figure 3.1). It also tells us the sampling frequency and where the sample of this material is taken. As well as the range of values that they must have at the time of carrying out the tests that correspond to them to know if the material is in the appropriate conditions for its use.

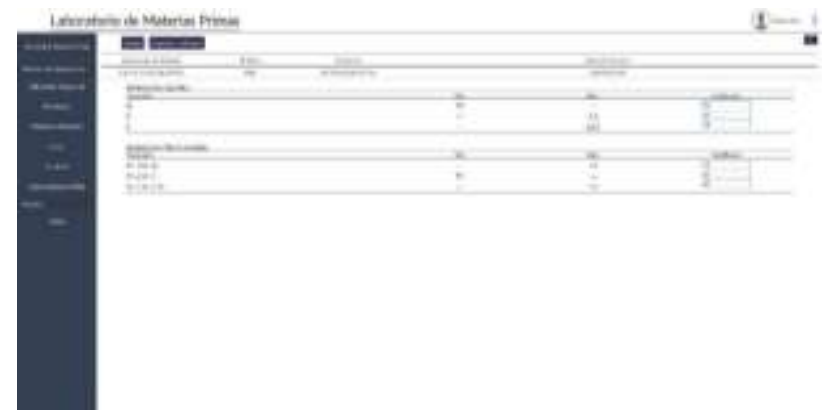

Figure 5 Receipt of Raw Materials

Figure 6 shows the materials that still have pending analysis to be done. Which correspond to the Raw Materials Laboratory. The tests are Granulometry, Humidity and Density.
We choose a material indicating to the user the analysis corresponding to the chosen material.

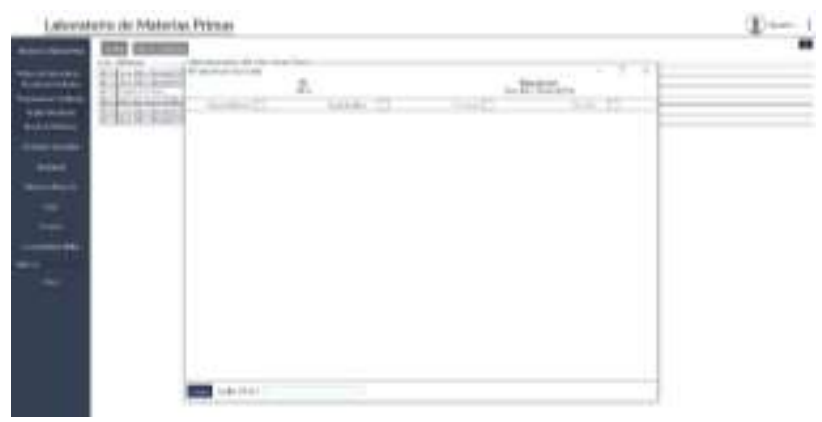

Figure 6 Pending Preparations

Next, in figure 7 , the data that the user must register in case of requiring a normal Granulometry test is shown.

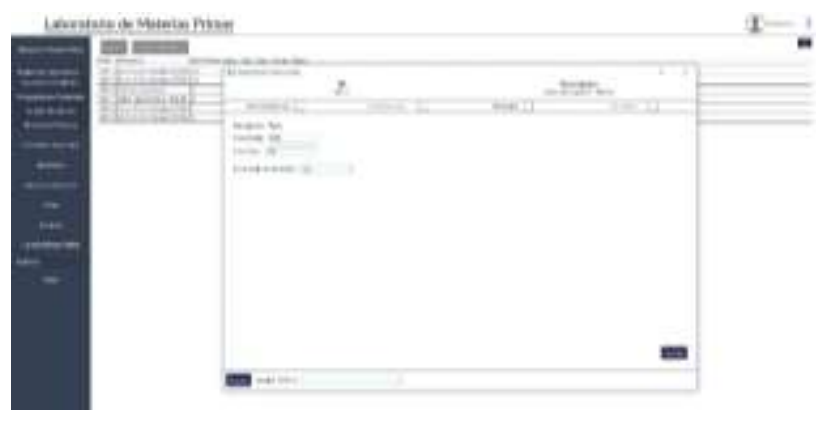

Figure 7 Pending Preparations

Next, in figure 8 , the data that the user must register in case of requiring a special Granulometry test is shown.

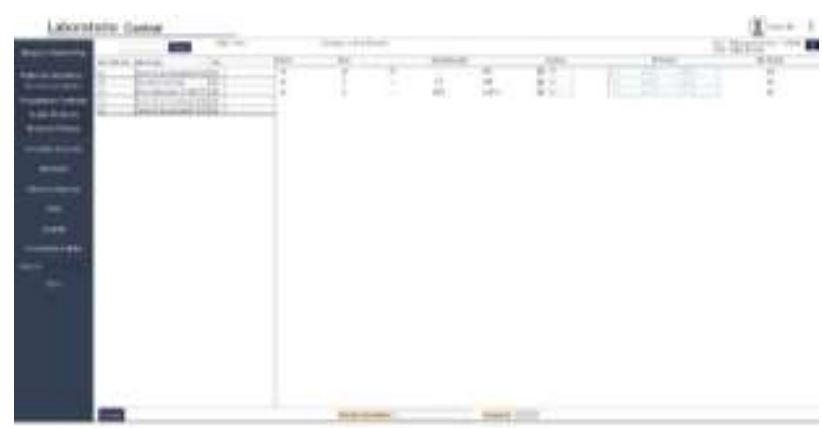

Figure 8 Pending Analysis

\section{Results}

With the system developed, the records that are carried out in the areas of raw materials and central laboratory were automated. Likewise, the time in traceability processes was reduced because users of central laboratory and raw materials will be able to see the results instantly without having to wait for them to take them personally. 
With this system developed the area of raw materials and central laboratory will have adequate communication with the results of the tests that correspond to each one, as well as being able to release the materials more quickly and timely for their use in production, reducing Registry errors and ensure that your raw material contains the necessary values so that your final product obtains the required quality. The response time improved to 1 day, since it took 5 to 7 days as a precedent for this process. It is recommended to keep the database, computer equipment and communication networks updated so that in this way the data that is handled in real time significantly improves the operational processes.

\section{Future work}

In this first stage the system was designed and implemented, once this stage is completed the next will be to establish the direct connection between the sensors and the system developed to automate processes without human intervention, implementing IOT technology.

\section{Acknowledgments}

The facilities provided for the realization of this article to the Autonomous University of Coahuila are appreciated.

\section{References}

Acosta , D. A., \& Navarrete , G. (2013). Importancia del uso del software contable en pequeñas, medianas y grandes empresas del cantón Portoviejo. La Tècnica(10), Pp. 62-72.

Garrido, B.S., Diseño de Bases de Datos - Un enfoque práctico. Edición Kindle, 2014.

Hernández , A. (2003). Los sistemas de información: evolución y desarrollo. Proyecto social: Journal de relaciones laborales, (10), Pp. 149-165.

Mariño, S. I., \& Alfonzo, P. L. (2014). Implementación de SCRUM en el diseño del proyecto del Trabajo Final de Aplicación. Scientia Et Technica, 19(4), Pp. 413-418.

Lozano, M. (2000). Ingeniería del software y bases de datos: tendencias actuales. España: ediciones de la Universidad de Castila-La Mancha.
Pressman, R. (2010). Ingeniería de software: Un enfoque practico, Séptima Edición. McGrawHill.

Sharp, J. (2018). Microsoft Visual C\# Step by Step (9th Edition ed.). Redmond, Washington: Microsoft Press.

Sutherland, J., Viktorov, A., Blount, J., \& Puntikov , N. (2007). Distributed Scrum: Agile Project Management with Outsourced Development. 40th Annual Hawaii International Conference on System Sciences (págs. Pp. 274a274a). Waikoloa, HI, USA: IEEE. doi:10.1109/HICSS.2007.180 